DOI 10.37882/2223-2982.2021.04.08

\title{
МОДАЛЬНЫЕ ГЛАГОЛЫ КАК ПРЕДМЕТ ОБУЧЕНИЯ ПРОФЕССИОНАЛЬНО-ОРИЕНТИРОВАННОМУ ЧТЕНИЮ СТУДЕНТОВ НЕЯЗЫКОВЫХ СПЕЦИАЛЬНОСТЕЙ
}

\section{MODAL VERBS AS A SUBJECT OF TRAINING PROFESSIONAL-ORIENTED READING FOR STUDENTS OF NON- LANGUAGE SPECIALTIES}

E. Galizina

Summary: The aim of the research is to consider and systematize English modal verbs in the process of teaching professionally oriented reading to students of non-linguistic specialties. The article analyzes educational standards, competence-based approach and methods of forming professionally oriented reading skills. The scientific novelty of the research lies in the selection and systematization of modal verbs for the needs of professionally oriented reading.

As a result, it was proved that the system of interconnections of English modal verbs can contribute to overcoming the difficulties associated with the passage of this section of grammar.

Keywords: professionally oriented reading, modal verbs, competencebased approach.

\section{Введение}

A ктуальность темы исследования обусловлена недостаточностью системного описания значений модальных глаголов в грамматических справочниках английского языка и специальных пособиях. Следует отметить, что многочисленные описания значений каждого глагола в отдельности не позволяют создать правильной картины их функционирования в речи, оставляют без объяснения ряд частотных реальных случаев употребления, что приводит к ошибочным представлениям о значении этих глаголов и их роли в речи. У зарубежных и отечественных лингвистов существуют различные и многообразные определения категории модальных глаголов. Это объясняется тем, что исследователи базируются на разнородных критериях: психологических, логических и субъективных.

Целью данной статьи является рассмотрение модальных глаголов в процессе обучения профессионально-ориентированному чтению студентов неязыковых специальностей и применение, полученных в ходе теоретического рассмотрения результатов к практике преподавания английского языка. Для достижения указанной цели исследования необходимо решить следующие
Гализина Елена Григорьевна

К.п.н., дочент, Московский государственный институт физической культуры, спорта и туризма им. Ю.А. Сенкевича; Российский университет транспорта

(РУТ МИИТ)

el.galizina@yandex.ru

Аннотация: Цель исследования - рассмотреть и систематизировать английские модальные глаголы в процессе обучения профессионально-ориентированному чтения студентов неязыковых специальностей. В статье анализируются образовательные стандарты, компетентностный подход и методика формирования навыков профессионально ориентированного чтения. Научная новизна исследования заключается в отборе, систематизации модальных глаголов для нужд профессионально-ориентированного чтения.

В результате доказано, что система взаимосвязей английских модальных глаголов может стать вкладом в преодоление трудностей, связанных с прохождением данного раздела грамматики.

Ключевые слова: профессионально-ориентированное чтение, модальные глаголы, компетентностный подход.

задачи: во-первых, исследовать модальные глаголь в рамках обучения профессионально-ориентированному чтению студентов неязыковых специальностей; во-вторых, отобрать и систематизировать модальные глаголы и организовать их презентацию; в-третьих, обосновать формирование навыков профессионально-ориентированного чтения у студентов неязыковых специальностей на примере модальных глаголов.

Для рассмотрения модальных глаголов, как предмета обучения профессионально-ориентированному чтению студентов неязыковых специальностей в статье применяются следующие методы исследования: компетентностный подход и методика обучения профессионально-ориентированному чтению.

Теоретической базой исследования послужили публикации как отечественных, так и зарубежных авторов: R. Quirk, S. Greenbaum, G. Leech, J. Svartvik [8], Е.И. Беляева [1] и др., в которых рассматривается категория модальности.

Практическая значимость исследования заключается в том, что раскрываемая в статье методика формирования навыков профессионально-ориентированного 
чтения (на примере модальных глаголов) может быть использована в образовательном процессе по английскому языку на неязыковых специальностях.

Основной задачей обучения иностранному языку в неязыковом вузе является профессиональная ориентация в изучении данной учебной дисциплины.

При обучении иностранному языку студентов неязыковых специальностей главное внимание следует уделять повышению эффективности обучения, в аспекте чтения литературы по специальности и устного высказывания на профессионально-ориентированные темы.

Чтение иноязычных текстов профессиональной тематики предусматривает знание определенного словарного запаса по специальности и ориентацию в грамматической структуре предложения, так как качество чтения зависит, главным образом, от знания грамматики.

А.А. Вербицкий, указывает на взаимосвязь профессиональной деятельности студентов с деятельностью педагога. Следовательно, преподаватель иностранного языка неязыкового вуза должен научить своих студентов использовать иностранный язык как инструмент своей профессиональной подготовки. Обучение иностранному языку должно исходить из принципа профессиональной направленности при подготовке всесторонне развитых специалистов. Содержание обучения этой учебной дисциплине, таким ее аспектам как грамматика, неразрывно связано с общим содержанием профессионального образования в высшем учебном заведении [2, c. 202].

В 21 веке общество столкнулась с проблемой отсутствия достаточного количества кадров, способных сразу после окончания вуза компетентно работать в новых условиях. Ситуация, когда специалист с высшим образованием имеет конечный объем знаний при отсутствии умении их использовать и пополнять, становится сдерживающим фактором развития производительных сил общества. Этим обусловлено обращение европейского, а вслед за ним и российского образования к компетентностному подходу. Согласно компетентностному подходу образовательные учреждения должны формировать новую систему универсальных знаний, умений, навыков, опыт самостоятельной деятельности и личной ответственности обучающихся [2, с. 104].

И.А. Зимняя называет пять причин ориентации на компетентностный подход в образовании: 1) тенденция интеграции и глобализации мировой экономики; 2) необходимость гармонизации архитектуры европейской системы высшего образования, заданная Болонским процессом; 3) происходящая в последнее время смена образовательной парадигмы; 4) богатство понятийно- го содержания термина «компетентностный подход»; 5) предписания органов управления образованием [4, c. 79]

Подготовка студентов неязыковых специальностей с умением общаться на английском языке непосредственно связана с модернизацией системы российского образования. На данном этапе оно проходит стадию реформирования - меняются требования к результатам обучения, совершенствуются программы обучения, перенимается опыт зарубежных высших учебных заведений, налаживается совместная работа российских и иностранных учебных заведений. В настоящее время проводится разработка и принятие новых учебных программ по языку в соответствии с государственным образовательным стандартом высшего образования в компетентностном формате, уточняются определения и классификации компетенций, а также их содержание, которое соответствует задачам обучения общению специалистов на английском языке [7].

В соответствии с федеральным государственным стандартом высшего образования разработана рабочая учебная программа дисциплины «Иностранным язык в профессиональной деятельности» (Бакалавр), где четко отражены следующие цели и задачи учебной дисциплины:

- цель учебной дисциплины заключается в приобретении студентами знаний иностранного языка соотнесенное с общими целями ООП ВПО, с последующим применением его на практике в научно-исследовательской и профессиональной деятельности;

- задачи учебной дисциплины:

- формирование представлений о нормах изучаемого языка в традиционной общелитературной области, сфере официально-делового общения, в профессиональной сфере;

- развитие умений иностранного языка в межличностном общении и профессиональной деятельности

- овладение навыками, навыками разговорной речи на иностранном языке, ведения дискуссии, полемики, диалога; навыками аннотирования, реферирования профессионально-ориентированного перевода [7].

На первый план выходит компетентностно-ориентированное образование, следовательно, российские стратегические документы в области подготовки специалистов с высшим образованием направлены на формирование системы универсальных знаний, умений, навыков и ключевых компетенций, определяющих современное качество образования. Что касается предмета «Иностранный язык», то в соответствии с новыми образовательными стандартами, также выдвигаются 
новые требования по формированию общекультурных и профессиональных компетенций. Процесс освоения учебной дисциплины направлен на формирование у обучающихся следующих общекультурных компетенций:

- способность к коммуникации в устной и письменной формах на русском и иностранном языках для решения задач межличностного и межкультурного взаимодействия;

- способность работать в коллективе, толерантно воспринимая социальные, этнические, конфессиональные и культурные различия;

- способность к самоорганизации и самообразованию [7].

Практическая реализация компетентностного подхода может осуществляться с учетом педагогических особенностей по формированию лексико-грамматических навыков профессионально-ориентированного чтения.

Профессионально-ориентированное чтение - это сложная речевая деятельность, обусловленная профессиональными возможностями и потребностями, представляющими собой специфическую форму активного вербального письменного общения-диалога, основными целями которого являются оперативная ориентация и поиск, прием, присвоение и последующее целевое применение накопленного человеческого опыта в профессиональных областях знаний [5, с.143].

Для методики обучения профессионально-ориентированному чтению очень важно, чтобы неусвоенная речевая операция формировалась в процессе речевого действия, чтения и повторялась в нем, направляемая сознательной целью столько раз, пока она не станет условием, способом сложного речевого действия [6, с. 106].

Контекст обучения профессионально-ориентированному чтению означает неконтактное общение читателя с автором, осуществляемое через текст, содержащий мысли автора. В данной цепочке: автор - текст - читатель, задача читателя сводится к извлечению из текста авторской мысли, информации. Все сгустки такой информации, заключенные в тексте, передаются исключительно средствами языка - в первую очередь лексическими и грамматическими единицами.

В данной статье предлагается рассмотреть модальные глаголы при обучении чтению профессиональноориентированных текстов.

Поскольку профессионально-ориентированные тексты изобилуют употреблением модальных глаголов разного вида, была предпринята попытка создать модель обучения чтению на примере этих глаголов.

Интерес представляют исследования, основываю- щиеся на принципе грамматического анализа «от значения к форме» и «от формы к значению», опираясь на которые выдвинута идея активной и пассивной грамматики. Для изучаемой проблемы методически значимым является исследование функциональной грамматики, где рассматривается выполнение языковыми единицами разнообразных функций, имеющих потенциальный и целевой аспекты. Потенциальный аспект предполагает способность некоторой единицы реализовывать цели. При отборе и систематизации грамматических средств английского предложения необходимо учитывать этот потенциальный аспект. Целевой аспект предусматривает реализацию указанной способности в речевом высказывании - в тексте. Отличия одного аспекта от другого состоят в том, что функциональный потенциал единицы заключен в систему языка, а реальная функция в речи $[1$, c.25]

Были исследованы английские профессиональноориентированные тексты с их модальной структурой. Известно, что тексты профессиональной направленности содержат категорию модальности, которая выражена, прежде всего, модальными глаголами.

Модальные глаголы - широкоупотребительная группа слов, выражающих в английском языке отношение автора к содержанию высказывания. Синтаксической особенностью их является то, что они входят в состав сказуемого предложения и потому их вводный характер не сразу очевиден. Иными словами, общая формула высказывания, включающего модальный элемент M (N - V) в случае модальных глаголов принимает вид $\mathrm{N}-\mathrm{M}-\mathrm{V}$, где $\mathrm{V}$ всегда инфинитив. В рамках данного описания самая примечательная особенность модальных глаголов способность каждого из них быть соотнесенными с обеими указанными ситуациями при сохранении единства своего индивидуального значения.

К данной группе модальных глаголов по традиции относятся как собственно модальные глаголы can/could, may/might, must, shall, should, ought, will/would, так и эквиваленты to be to $и$ to have to при их употреблении в положении между подлежащим и инфинитивом. Общепринято относить две первые группы глаголов - can/could, may/might - к глаголам, выражающим возможность-вероятность события, а глаголы must, shall, should, ought и их эквиваленты to be to и to have to рассматривать как глаголы долженствования. При этом последняя пара will/would остается за рамками классификации.

Это ряд составлен на основе сформулированного основного смысла всех употреблений каждого глагола, который сохраняется во всех контекстах. Этот основной смысл каждого глагола по сравнению со смыслами остальных глаголов формулируется таким образом, кar если бы автор пытался обосновать свое отношение к N - 
V. При такой формулировке значения модальных глаголов могут быть записаны следующим образом.

Автор считает N - V необходимым и объясняет почему:

must - потому что по его мнению альтернатива исключена;

to have to - потому что к этому вынуждают обстоятельства;

to be to - потому что N - V запрограммировано;

shall - потому, что $\mathrm{N}$ - V зависит от посторонней воли.

Автор считает $N$ - V желательным и объясняет почему:

ought - потому, что в пользу этого существуют общепринятые доводы;

should - потому, что таково личное мнение автора и его эмоции.

Автор считает $\mathrm{N}$ - V допустимым т объясняет почему:

may - потому что существует возможность альтернативного развития событий;

might - потому, что среди возможных альтернатив $\mathrm{N}-\mathrm{V}$ не исключено.

Автор считает $N$ - V реально осуществимым и объясняет почему:

can - потому что для этого есть необходимые условия и нет препятствий;

could - потому, что для этого есть необходимые условия, если нет никаких препятствий.

Aвтор считает N-V естественным и объясняет почему:

will - потому, что в поведении субъекта наблюдается активное стремление к $\mathrm{N}-\mathrm{V}$;

would - потому, что такова наблюдавшаяся в прошлом или ожидаемая тенденция развития событий.

Такая интерпретация индивидуальных значений модальных глаголов в основном не вступает в противоречие с их традиционным описанием в большинстве грамматик.

Наблюдение над употреблением модальных глаголов в профессионально-ориентированных текстах свидетельствует о том, что их роль не исчерпывается их использованием и модальные глаголы служат сигналом авторской позиции для оценки степени достоверности $\mathrm{N}-\mathrm{V}$.

Из вышеизложенного хотелось бы подчеркнуть ряд важнейших для преподавателя моментов, вытекающих из предложенной системы рассмотрения модальных глаголов.

1. Все модальные глаголы, как выразители отношения автора к высказыванию, однозначны, и значение каждого не зависит ни от контекста в целом, ни от содержания того предложения, в котором этот глагол употреблен.
2. Употребление того или иного глагола в конкретном случае, как правило, определяется не содержанием высказывания, а замыслом автора, который становится понятным из широкого контекста. Исключение составляют высказывания типа сентенций, которые не нуждаются в более широком контексте. Это нужно брать во внимание при составлении упражнений (в частности, на заполнение пропусков модальными глаголами). Для того чтобы выбор того или иного глагола был однозначным, предложение должно включать элемент обоснования автором своей позиции. В противном случае выполнение упражнения становится произвольным.

3. Основным значением рассмотренных глаголов является значение модальности. Использование некоторых из них для образования грамматических форм времени и наклонения не исключает сохранения этими глаголами своего основного смысла. Употребление же модальных глаголов в профессионально-ориентированном тексте свидетельствует о том, что использование данных глаголов как чисто модальных является более частотным.

4. В практике преподавания целесообразнее уделять основное внимание лексическому значению этих глаголов и рассматривать будущее время и сослагательное наклонение как частный случай реализации значения этих модальных глаголов.

5. Правило согласования времен действует в отношении модальных глаголов весьма ограниченно. Глаголы must, may, can, will используются достаточно регулярно для выражения авторского отношения к событиям прошлым или в контексте, который по правилам требует их замены формами прошедшего времени. Замена must на had to практически почти не наблюдается. Эти два глагола функционируют каждый со своим значением [3, c. 145].

Приведем несколько примеров:

1. Since the sun and the moon manifestly influenced the earth, astrological doctrine held that the planets must affect human life too, but in more subtle ways. Поскольку Солнце и Луна явно влияют на Землю, астрологическая доктрина утверждала, что планеты несомненно влияют и на жизнь людей, хотя и менее явным образом.

2. It is hard to believe that the ancient people should have known that it is possible to win energy from heavy metals and how to do so. Трудно поверить, что в древности люди могли знать о возможности получения энергии из тяжелых металлов и о том, как это сделать.

3. People would close their eyes to new realities. Людям свойственно закрывать глаза на то новое, что 
возникает в действительности.

4. Research does not become possible until the thing that is to be investigated has actually been found. Научное исследование становится возможным только после того, как то, что предстоит исследовать, действительно найдено.

5. Here one can find rock vitrifications of a kind that ought only to be possible through the melting of stones at extremely high temperatures. Здесь можно найти такие стекловидные образования, которые по всей видимости, можно получить в результате плавления породы при очень высокой температуpe.

\section{Зак^ючение}

Таким образом, мы пришли к следующим выводам. При обучение профессионально-ориентированному чтению студентов неязыковых специальностей (на примере модальных глаголов) важно, чтобы обучаемые видели за набором отдельных слов, каковым им прежде всего представляется воспринимаемое предложение, определенную грамматическую взаимосвязь этих слов. Имеются все основания для изучения категории модальности профессионально-ориентированных текстов, а система взаимосвязей английских модальных глаголов может стать вкладом в преодоление трудностей, связанных с прохождением данного раздела грамматики.

Перспективы дальнейшего исследования мы видим в более подробном изучении категории модальности. Следует обратить внимание при формировании навыков профессионально-ориентированного чтения у студентов неязыковых специальностей на модальные конструкции, модальные слова, модальные фразы и модальные частицы.

\section{ЛИТЕРАТУРА}

1. Беляева Е.И. Функционально-семантические поля модальности в английском и русском языках. Воронеж.: Изд-во Воронеж. ун-та, 1985. 179 с.

2. Вербицкий А.А., Ларионова О.Г. Личностный и компетентностный подходы в образовании: проблемы интеграции. М.: Логос, 2009. 336 с.

3. Гализина Е.Г. Лингводидактические особенности формирования навыков профессионально-ориентированного чтения на английском языке (грамматический аспект): дисс. ... к. пед. н. Воронеж, 1998. 159 с.

4. Зимняя И.А. Ключевые компетентности как результативно-целевая основа компетентностного подхода в образовании. М.: ИЦПКПС. 2004. 202 с.

5. Серова Т.С. Профессионально-ориентированное чтение как компонент профессиональной деятельности и его основные функции // Виды речевой деятельности в системе профессионально-ориентированного обучения иностранному языку. Пермь. 1986. С. 143-146.

6. Серова Т.С. Психологические и лингводидактические аспекты обучения иноязычному чтению в вузе. Свердловск: Уральский университет, 1988. 232 с.

7. Федеральный государственный образовательный стандарт высшего образования (ФГОС В0) нового поколения. [Электронный ресурс]: http://www.edu. abitur|act.82|idex/php. (дата обращения 10.03.2021).

8. Quirk R., Greenbaum S., Leech G., Svartvik J.A Comprehansive Grammar of the English Language. Longman, 1985. 224 p. 